\title{
NHÂN MỘT TRƯờnG HỢP THIẾU MÁU ĐẠI TRÀNG SAU THAY ĐOẠN ĐộNG MẠCH CHỦ BỤNG - KẾT QUẢ VÀ NHÌ̀ LẠI Y VĂN
}

\section{Dưong Ngọc Thắng*, Nguyễn Hũu Uớc*, Phạm Phúc Khánh**, Trần Hũu Nghị*}

\section{TÓM TÁT}

Tổng quan: Thiếu máu đại tràng là một biến chứng ít gặp nhưng rất nguy hiểm trong phẫu thuật thay đoạn động mạch chủ bụng. Các yếu tố nguy cơ biến chứng gồm có: tuổi cao, suy thận trước mổ, phồng động mạch chủ bụng vỡ, thời gian mổ kéo dài, không tái lập tuần hoàn động mạch chậu trong. Chẩn đoán sớm bằng soi đại tràng. Điều trị bằng phẫu thuật cắt đoạn đại tràng nếu còn chỉ định với tiên lượng nặng. Tỷ lệ tử vong cao do viêm phúc mạc và sốc nhiễm trùng. Can thiệp nội động mạch chủ bằng stentgraft có tỉ lệ gặp biến chứng này thấp hơn.

Phương pháp nghiên cúu: dựa trên một ca lâm sàng tại bệnh viện Hữu nghị Việt Đức và nhìn lại y văn, báo cáo nhằm mô tả các yếu tố nguy cơ, các phương pháp chẩn đoán sớm và giải pháp điều trị đối với loại biến chứng nặng nề này.

Truờng hợp lâm sàng: Bệnh nhân nam 81 tuổi, tiền sử tăng huyết áp và nhiều yếu tố nguy cơ khác, được phẫu thuật thay đoạn động mạch chủ bụng - chậu do phồng động mạch, dấu hiệu biến chứng hoại tử đại tràng trái xuất hiện rõ vào ngày thứ 4 sau phẫu thuật, được điều trị thành công bằng phẫu thuật cắt đoạn đại tràng cấp cứu.

Kết luận: Các yếu tố nguy cơ thiếu máu đại tràng sau phẫu thuật thay đoạn động mạch chủ bụng rất đa dạng. Chẩn đoán sớm khó khăn, tốt nhất bằng soi đại tràng. Phẫu thuật cắt đoạn đại tràng nếu còn chỉ định với tiên lượng nặng, tỉ lệ tử vong cao. Can thiệp nội mạch có thể làm giảm tỉ lệ biến chứng.

Tù khóa: thiếu máu đại tràng, phồng động mach chủ bung, thay đoan.

PROPOSE A CASE OF COLON ISCHEMIA AFTER ABDOMINAL AORTIC REPLACEMENT SURGERY - RESULTS AND REVIEW OF LITERATURE

\section{ABSTRACT}

Overview: Colonic ischemia is a rare but very dangerous complication in abdominal aortic replacement surgery. Risk factors for complications include: elderly, preoperative renal failure, ruptured abdominal aortic aneurysm, prolonged operation time, no re-circulation of the internal iliac artery. Early diagnosis by colonoscopy. Treatment with surgical colonectomy if still indicated with a severe prognosis. High mortality due to peritonitis and septic shock. Aortic intervention with stentgraft has a lower incidence of this complication.

Method: based on a clinical case at Viet Duc Hospital and review of literature, report to describe risk factors, early diagnosis methods and treatment solutions for variable type this severe complication.

\footnotetext{
* Trung tâm Tim mạch và Lồng ngưcc, bệnh viện Hũu nghị Việt Đức

** Trung tâm Hậu môn Trục tràng, bệnh viện Hũu nghị Việt Đức Nguoòi chịu trách nhiệm khoa họ: Duong Ngọc Thắng
}

Ngày nhận bài: 02/02/2021 - Ngày cho phép đăng: 07/04/2021 
Clinical case: A male patient - 81 years old, a history of hypertension and many other risk factors, surgery to replace the abdominal aorta segment due to aneurysm, signs of complications of left colon necrosis clearly appeared on the 4th day after surgery, successfully treated with colonectomy in emergency.

Conclusion: Risk factors for colonic ischemia after abdominal aortic replacement surgery are diverse. Early diagnosis is difficult, preferably with colonoscopy. Colonectomy if still indicated with a severe prognosis, high mortality rate. Intravascular intervention may reduce the incidence of complications.

Key words: Colonic ischemia, abdominal aortic aneurysm, replacement.

\section{TỔNG QUAN}

Thiếu máu đại tràng sau phẫu thuật thay đoạn động mạch chủ bụng (ĐMCB) là biến chứng hiếm gặp, có biểu hiện lâm sàng ở 1-3\% tổng số các ca phẫu thuật hoặc can thiệp ĐMCB có kế hoạch [1], và chiếm khoảng $10 \%$ các trường hợp phồng ĐMCB vỡ [2], đây là biến chứng nặng nề với tỉ lệ tử vong rất cao. Ngày nay $\mathrm{xu}$ hướng điều trị chung cho phồng $\mathrm{ĐMCB}$ nghiêng về kỹ thuật can thiệp nội mạch bằng stentgraft, với các tiến bộ đáng kể trong kỹ thuật, tỉ lệ biến chứng và tử vong sớm sau can thiệp nội mạch đã giảm đi đáng kể so với phẫu thuật kinh điển. Y văn thế giới cũng đã có nhiều nghiên cứu về biến chứng thiếu máu đại tràng sau phẫu thuật ĐMCB trên số lượng lớn bệnh nhân, trong khi ở Việt Nam, chưa thấy nhiều báo cáo liên quan đến biến chứng này. Tại trung tâm Tim mạch và Lồng ngực, bệnh viện Hữu nghị Việt Đức, hiện đã thực hiện phẫu thuật và can thiệp hàng trăm ca phồng
ĐMCB mỗi năm, tuy nhiên biến chứng thiếu máu đại tràng rất hiếm được quan sát thấy. Nhân một trường hợp hoại tử toàn bộ đại tràng trái sau phẫu thuật thay đoạn ĐMCB được chẩn đoán và điều trị thành công, chúng tôi báo cáo và đối chiếu với y văn nhằm đưa ra định hướng chẩn đoán sớm và điều trị đối với những bệnh nhân có yếu tố nguy cơ cao.

\section{ĐỐI TƯợng VÀ PHƯƠNG PHÁP NGHIÊN CÚU}

Phương pháp mô tả ca lâm sàng tại bệnh viện Hữu nghị Việt Đức trong năm 2020, và nhìn lại y văn về chẩn đoán và điều trị một bệnh hiếm gặp: "thiếu máu đại tràng sau phẫu thuật thay đoạn động mạch chủ bụng”.

\section{TRƯỜNG HỢP LÂM SÀNG}

Bệnh nhân L.T.S, nam 81 tuổi, tiền sử phẫu thuật tuyến giáp cách 1 năm (không rõ kết quả giải phẫu bệnh), tăng huyết áp mới phát hiện chưa điều trị, không có tiền sử đái tháo đường; được đưa đến bệnh viện Hữu nghị Việt Đức do đau bụng quanh rốn, tình trạng huyết động ổn định, mạch 100 lần/phút, huyết áp 150/100mmHg. Các xét nghiệm cơ bản gồm: công thức máu, đông máu cơ bản bình thường; chức năng thận giảm nhẹ (ure 9,1 mmol/1; creatinin $134,75 \mu \mathrm{mol} / 1)$. Kết quả chẩn đoán hình ảnh hệ mạch máu có hẹp 50\% động mạch (ĐM) cảnh gốc phải. Siêu âm tim thấy tăng gánh thất trái, phân số tống máu bình thường; chụp mạch vành tầm soát có vôi hóa nhẹ ĐM liên thất trước và ĐM mũ. Phim chụp cắt lớp vi tính đa dãy có tiêm thuốc và dựng hình (MSCT) của ĐMCB thấy: hình ảnh khối phồng ĐMCB dưới chỗ chia ĐM thận, đường kính $56 \mathrm{~mm}$ trên đoạn dài $58 \mathrm{~mm}$; ĐM chậu chung trái đường 
kính 20mm, ĐM chậu chung phải đường kính tạng; ĐM mạc treo tràng trên (ĐMMTTT) 15mm; hẹp 30-40\% ĐM chậu trong 2 bên; hẹp không hẹp; hẹp 40\% gốc ĐM mạc treo tràng $50 \%$ gốc ĐM thận phải, hẹp 50\% ĐM thân dưới (ĐMMTTD).

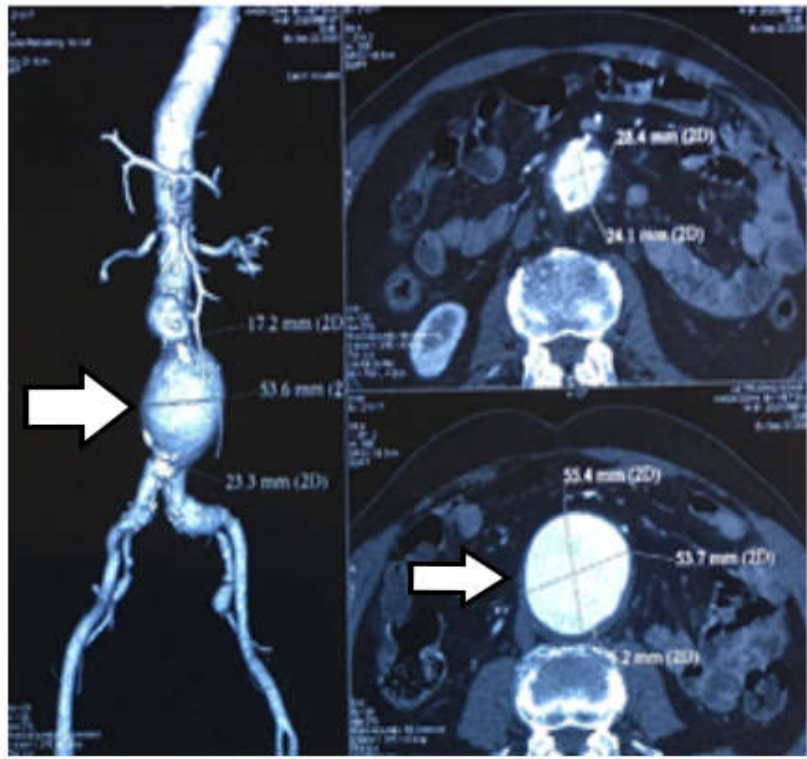

Phồng ĐMCB dưới thận / MSCT

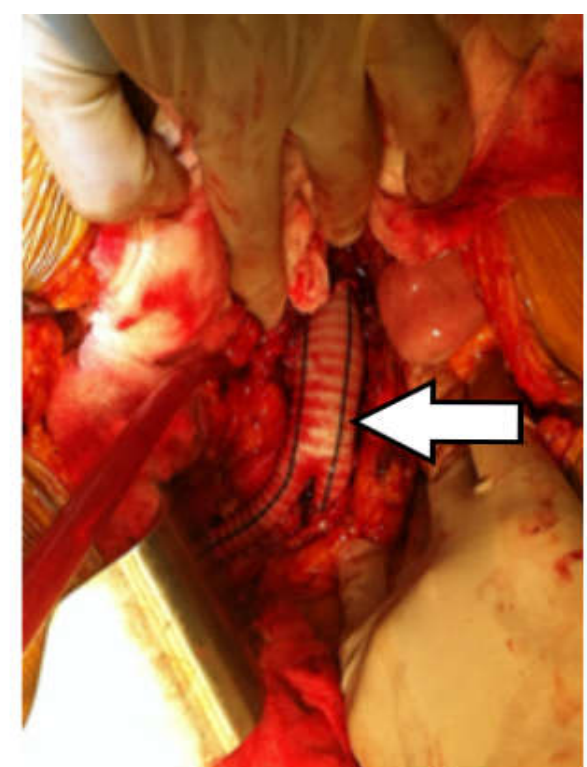

Thay đoạn ĐM chủ-chậu bằng mạch nhân tạo chữ $Y$

Hình 1. Phim chụp MSCT hệ ĐM chủ - chậu trước mổ và sau thay đoạn mạch nhân tạo

Bệnh nhân được điều trị nội khoa 14 ngày và phẫu thuật có chương trình ngày $05 / 10 / 2020$. Thương tổn trong mổ được xác định bao gồm: ĐMCB vôi hóa nhiều, phồng từ dưới chỗ chia ĐM thận khoảng $25 \mathrm{~mm}$, đường kính $60 \mathrm{~mm}$ đến chạc ba chủ chậu, tắc hoàn toàn ĐMMTTD ở sát gốc. Phồng ĐM chậu gốc 2 bên kích thước $20 \mathrm{~mm}$, vôi hóa nhiều ĐM chậu trong - ngoài. Xử trí thương tổn: thay đoạn ĐM chủ - chậu bằng đoạn mạch nhân tạo chữ $\mathrm{Y}$ (B-braun) đường kính 16-8mm; hai nhánh được nối vào chạc ba ĐM chậu 2 bên để bảo tồn ĐM chậu trong 2 bên; thắt ĐMMTTD sát gốc. Tổng thời gian phẫu thuật là 4 giờ trong đó thời gian kẹp ĐMCB dưới chỗ chia ĐM thận hai bên là 70 phút.

Diễn biến sau mổ: toàn trạng ổn định trong
3 ngày đầu, huyết áp tâm thu 150-160mmHg, được điều trị bằng nicardipin truyền tĩnh mạch liên tục. Ổ bụng có nhu động ruột vào ngày thứ 2 sau mổ; tới ngày thứ 3 xuất hiện chướng bụng nhẹ, đau tức quanh rốn, được đặt ống thông dạ dày, hậu môn, và chụp MSCT kiểm tra - thấy có hình ảnh tụ máu ít quanh mạch nhân tạo và tiểu khung, không có điểm chảy máu hoạt động, các quai ruột giãn to, ĐM chậu trong 2 bên ngấm thuốc tốt (Hình 2). Ngày thứ 4 sau mổ, chướng bụng tăng dần và ấn đau phản ứng nửa bụng trái, ống thông dạ dày ra dịch đen, ống thông hậu môn không ra hơi, mạch nhanh 130 lần/phút, huyết áp tụt $80 / 50 \mathrm{mmHg}$. Các xét nghiệm cho thấy tình trạng sốc với hematocrit $18,8 \%$, bạch cầu $11,9 \mathrm{G} / 1$, ure $27,8 \mathrm{mmol} / \mathrm{l}$, creatinine 411,23 $\mu \mathrm{mol} / \mathrm{l}$, lactat $8,2 \mathrm{mmol} / \mathrm{l}$. Bệnh nhân được hồi 
sức tích cực và tiến hành phẫu thuật cấp cứu ngày 09/10/2020, bởi kíp phẫu thuật mạch máu và tiêu hóa, với chẩn đoán: "hoại tử do thiếu máu đại tràng sau mổ thay đoạn ĐM chủ- chậu”. Tổn thương xác định trong mổ: hoại tử đại tràng trái từ góc lách đến $1 / 3$ giữa trực tràng (Hình 3 ). Phương pháp phẫu thuật chính là “cắt đại tràng trái, đưa đại tràng ngang ra làm hậu môn nhân tạo kiểu Hartmann". Sau mổ bệnh nhân tiếp tục được điều trị tích cực phòng nhiễm trùng toàn thân, chống sốc, suy thận và nuôi dưỡng qua đường tĩnh mạch + ống thông dạ dày. Tới ngày thứ 8 sau mổ: bệnh nhân tỉnh táo, tự thở qua mở khí quản, không sốt $\left(36,5^{\circ} \mathrm{C}\right)$, mạch 90 lần/phút, huyết áp 150/90 mmHg (với nicardipin tĩnh

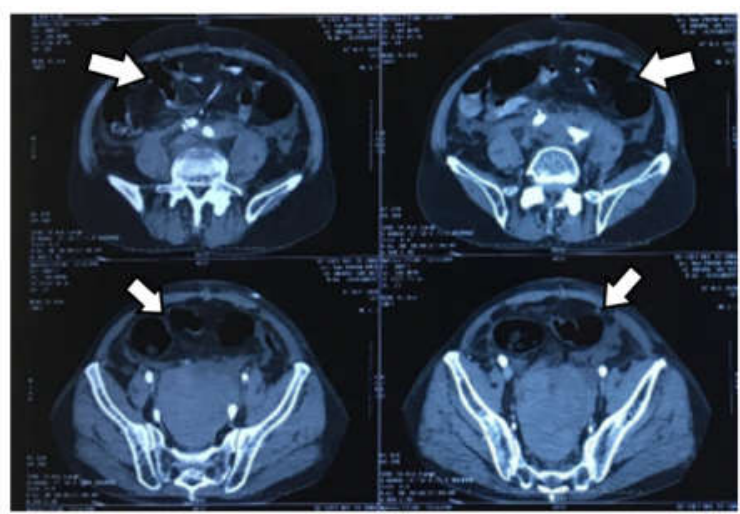

MSCT bụng ngày thứ 3 sau thay đoạn ĐMCB Các quai ruột giãn to. Không thấy biểu hiện chảy máu

Hình 2.

\section{BÀN LUẬN}

Thiếu máu đại tràng sau phẫu thuật ĐMCB là biến chứng rất nặng nề nhưng tương đối hiếm gặp: khoảng 1-3 \% đối với phẫu thuật và can thiệp động mạch chủ bụng có chuẩn bị, và khoảng $10 \%$ đối với phẫu thuật cấp cứu theo nghiên cứu của Becquemin thực hiện từ năm 1995 đến năm 2005 tại bệnh viện Henri Mondor (Cộng hòa Pháp), trên 1174 bệnh nhân mổ thay đoạn ĐMCB và đặt stentgraft ĐMCB [3]. Mặc dù gần đây đã có nhiều mạch phối hợp amlodipine $10 \mathrm{mg} /$ ngày và cozaar $50 \mathrm{mg} /$ ngày qua sonde dạ dày); bụng chướng nhẹ, hậu môn nhân tạo thông, đã rút các dẫn lưu ổ bụng; mạch chi dưới hai bên bắt rõ. Tới ngày thứ 15 sau phẫu thuật cắt đoạn đại tràng, tình trạng bệnh nhân ổn định, nuôi dưỡng qua ống thông dạ dày, hậu môn nhân tạo thông tốt, vết mổ thành bụng khô, đã rút ống mở khí quản, bệnh nhân được chuyển về bệnh viện tỉnh theo dõi và phục hồi chức năng.

Khám lại sau 4 tháng, bệnh nhân đi lại được, huyết áp kiểm soát tốt bằng amlodipin đường uống, hậu môn nhân tạo thông tốt, loét nhỏ vùng cùng cụt do nằm lâu, vết mổ thành bụng đã liền, mạch chi dưới hai bên rõ.

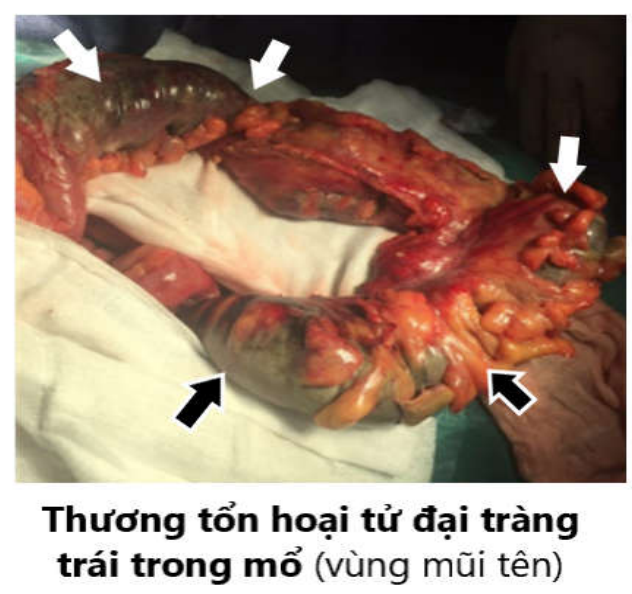

Hinh 3.

tiến bộ trong kỹ thuật phẫu thuật, can thiệp cũng như hồi sức sau mổ, tỉ lệ biến chứng này có giảm bớt nhưng cũng không nhiều. Nghiên cứu của Behrendt tại Đức từ năm 2008 đến năm 2017, trên 9145 bệnh nhân được phẫu thuật và can thiệp ĐMCB, cũng cho kết quả tương tự [4]. Biến chứng này quan sát thấy nhiều hơn trên bệnh nhân được phẫu thuật thay đoạn ĐMCB kinh điển (3-4\%), so với bệnh nhân được can thiệp nội mạch đặt stentgraft ĐMCB (1,4\%) [5]. 
Các nghiên cứu trên thế giới đã xác định được nhiều yếu tố liên quan đến hiện tượng giảm tưới máu ruột dẫn đến thiếu máu đại tràng sau phẫu thuật và can thiệp ĐMCB. Trước hết là các yếu tố nguy co độc lập thuộc về bệnh nhân gồm có: tuổi cao, tiền sử hút thuốc, bệnh lý suy thận mạn tính, do có liên quan trực tiếp đến hiện tượng xơ vữa hệ mạch máu, làm giảm lưu lượng máu cung cấp cho đại tràng trong quá trình phẫu thuật hay can thiệp ĐMCB [6]. Thêm vào đó, các bệnh nhân suy thận mạn tính thường có rối loạn về huyết động và phải sử dụng các thuốc lợi tiểu để duy trì lượng nước tiểu hàng ngày - trong đó có dopamin, nhóm thuốc này có tác dụng làm giảm $\mathrm{pH}$ niêm mạc đại tràng sigma, đây cũng là một yếu tố làm phát triển tình trạng thiếu máu đại tràng [7]. Các yếu tố nguy co liên quan đến phẫu thuật bao gồm: phồng ĐMCB vỡ và thời gian phẫu thuật. Nhiều nghiên cứu đều thống nhất rằng phồng ĐMCB đã vỡ là yếu tố nguy cơ liên quan chặt chẽ đến hiện tượng thiếu máu đại tràng sau phẫu thuật [2],[8]. Coppi nghiên cứu trên 124 trường hợp vỡ phồng ĐMCB với 33 trường hợp được điều trị bằng phương pháp can thiệp nội mạch thì thấy tỉ lệ thiếu máu đại tràng ở nhóm này là $3 \%$, thấp hơn so với nhóm được điều trị bằng phẫu thuật kinh điển $(8,7 \%)$ [9]. Becquemin cho rằng thời gian phẫu thuật kéo dài trên 4 giờ làm tăng đáng kể nguy cơ thiếu máu đại tràng sau phẫu thuật [3]. Bjork cũng cho rằng thời gian cặp ĐMCB là yếu tố liên quan có ý nghĩa với tình trạng thiếu máu ruột sau mổ [2]. Hai cơ chế chính gây nên tình trạng này là hiện tượng giảm lưu lượng máu đến ruột (trong khi cặp ĐMCB và co kéo mạc treo ruột trong mổ) và hiện tượng tái tưới máu ruột sau khi thả cặp. Các mô nhạy cảm nhất trong quá trình này là chi dưới và ruột. Khi tái tưới máu, các gốc oxy hóa tự do, neutrophils, enzyme xanthine oxidase, mitochondrial electron là các tác nhân chủ yếu làm tổn thương mô ruột [10]. Nghiên cứu của Khaira cũng chỉ ra rằng các yếu tố chống oxy hóa và gốc tự do có tác dụng bảo vệ tế bào bị giảm mạnh trong khoảng thời gian cặp ĐMCB và chỉ trở lại ngưỡng bình thường sau phẫu thuật 24 giờ [11]. Trong khoảng thời gian thiếu hụt các yếu tố bảo vệ này, các yếu tố oxy hóa có thể gây nên tình trạng thiếu máu ruột. Vai trò của lượng máu mất trong mổ đối với tình trạng thiếu máu đại tràng còn đang gây tranh cãi. Bjork [2] và Farooq [12] quan sát thấy tỉ lệ thiếu máu đại tràng tăng đáng kể ở nhóm bệnh nhân được truyền trên 10 đơn vị hồng cầu khối trong mổ. Các yếu tố liên quan đến giải phẫu mạch cấp máu cho ruột bao gồm ĐMMTTT, ĐMMTTD và ĐM chậu trong. Theo kinh nghiệm của chúng tôi, tái lưu thông ĐMMTTD trong phẫu thuật thay đoạn ĐMCB chỉ thực hiện trong trường hợp dòng phụt ngược của mạch máu này yếu; hoặc có thương tổn ĐMMTTT phối hợp / hoặc không bảo tồn được ĐM chậu trong hai bên. Đa số các trường hợp chúng tôi thắt ĐMMTTD sát gốc sau khi tái lập tuần hoàn ĐM chủ chậu. Các nghiên cứu khác đều cho thấy việc tái lập lưu thông ĐMMTTD không làm thay đổi nguy cơ tiến triển thiếu máu ruột sau phẫu thuật [3],[5]. Các tác giả cũng cho thấy, đối với những bệnh nhân được điều trị bằng phương pháp can thiệp nội mạch, che phủ hoàn toàn gốc ĐMMTTD bằng stent graft không làm tăng nguy cơ thiếu máu đại tràng sau can thiệp. Vai trò của vòng nối giữa ĐMMTTT và ĐMMTTD đối với sự tiến triển của tình trạng thiếu máu ruột chưa rõ ràng. Tuy nhiên các tác giả Dadian [13], Maldonado [5] thấy nguy cơ thiếu máu đại tràng sau can thiệp ĐMCB tăng lên đối với những bệnh nhân có tiền sử cắt đoạn đại tràng hay cắt khối tá tràng đầu tụy. Các phẫu 
thuật này trong quá khứ là nguyên nhân làm mất các vòng nối giữa ĐMMTTT và ĐMMTTD. Khác với các mạch máu cấp máu trực tiếp cho đại tràng, việc tái lập tuần hoàn $Đ M$ chậu trong hai bên có ý nghĩa trong việc làm giảm nguy cơ thiếu máu đại tràng. Nghiên cứu của Bjork [2] so sánh giữa nhóm được thắt một hoặc cả hai ĐM chậu trong (67 bệnh nhân) với nhóm được bảo tồn cả hai ĐM chậu trong (127 bệnh nhân) có tương ứng 22 bệnh nhân và 16 bệnh nhân tiến triển thành thiếu máu đại tràng với $\mathrm{OR}$ 2,6 [1,1-6,0 95\% CI]. Nghiên cứu của Becquemin cũng cho thấy tỉ lệ thiếu máu đại tràng ở nhóm được thay đoạn $\mathrm{ĐM}$ chủ - đùi cao hơn so với nhóm được thay đoạn ĐM chủ - chậu hoặc chỉ thay đoạn ĐMCB [3].

Nhờ vào sự phát triển của $\mathrm{y}$ học, phương pháp điều trị phồng $\mathrm{ĐMCB}$ bằng can thiệp nội mạch ngày càng được sử dụng rộng rãi mặc dù vẫn chưa thể thay thế hoàn toàn phẫu thuật kinh điển. Các nghiên cứu trên thế giới đều chỉ ra rằng tỉ lệ thiếu máu đại tràng thấp hơn có ý nghĩa ở nhóm bệnh nhân được can thiệp nội mạch. Giả thuyết được chấp nhận là cơ thể không sản xuất các yếu tố đáp ứng viêm khi không cặp ĐM chủ chậu như trong phẫu thuật kinh điển. Elmarasy [14] tiến hành định lượng các marker chỉ điểm tình trạng thiếu máu đại tràng gồm TNF-a, Interleukin6, Endotoxin trước, trong và sau can thiệp nội mạch so với phẫu thuật thì thấy nồng độ các chất này thấp hơn ở nhóm can thiệp nội mạch. Một giả thuyết khác lý giải nguyên nhân tiến triển của thiếu máu đại tràng sau can thiệp nội mạch là các vi huyết khối gây tắc các mạch thận, mạc treo và chậu trong. Các vi huyết khối này hình thành từ huyết khối bám thành ĐMCB hoặc mảng xơ vữa bị bong ra trong quá trình can thiệp nội mạch [5].

Chẩn đoán sớm thiếu máu đại tràng sau phẫu thuật hoặc can thiệp nội mạch ĐMCB hiện vẫn còn là một thách thức lớn. Các dấu hiệu lâm sàng xuất hiện từ ngày 0 đến ngày 13 sau phẫu thuật hoặc can thiệp bao gồm: sốt, dịch dạ dày đen bẩn, mất nhu động ruột (khi đặt ống thông dạ dày, hậu môn), đau, phản ứng thành bụng (giai đoạn muộn), tiêu chảy, xuất huyết tiêu hóa thấp, sốc nhiễm khuẩn, tụt huyết áp và suy đa tạng. Các xét nghiệm cận lâm sàng cũng không có ý nghĩa nhiều trong chẩn đoán, protein gắn acid béo ruột (I-FABP) là marker có ý nghĩa trong chẩn đoán sớm tuy nhiên khó thực hiện trong thực hành lâm sàng, trong khi đó d-lactat - sản phẩm hình thành do quá trình lên men của vi khuẩn trong ruột - dù dễ định lượng hơn, lại chỉ mang ý nghĩa dự đoán. Tiêu chuẩn chẩn đoán xác định thiếu máu đại tràng đến nay được chấp nhận là nội soi đại tràng (Hình 4). Levison [15] đưa ra khuyến cáo theo dõi bằng soi đại tràng trong 12 giờ sau phẫu thuật và nhắc lại mỗi 48 giờ đối với các bệnh nhân có ít nhất 3 yếu tố nguy cơ: huyết áp tâm thu $<90 \mathrm{mmHg}$; thời gian cặp ĐMCB $>30$ phút; thân nhiệt trong mổ $<35^{\circ} \mathrm{C}$; $\mathrm{pH}$ khí máu $<7,3$; truyền $>6$ đơn vị máu trong mổ; bù dịch trong mổ $>5$ lít. Trường hợp bệnh nhân trong nghiên cứu của chúng tôi các dấu hiệu lâm sàng diễn biến rất nhanh và rõ ràng, bệnh nhân nhanh chóng rơi vào tình trạng sốc nhiễm độc. Mặc dù tại bệnh viện Hữu nghị Việt Đức, kỹ thuật soi đại tràng đã trở thành thường quy, tuy nhiên việc triển khai thực hiện soi cấp cứu ngoài giờ hành chính vẫn cần thời gian và nhân lực. Vì vậy chúng tôi quyết định chỉ định phẫu thuật cấp cứu chỉ dựa trên các dấu hiệu lâm sàng và xét nghiệm. 

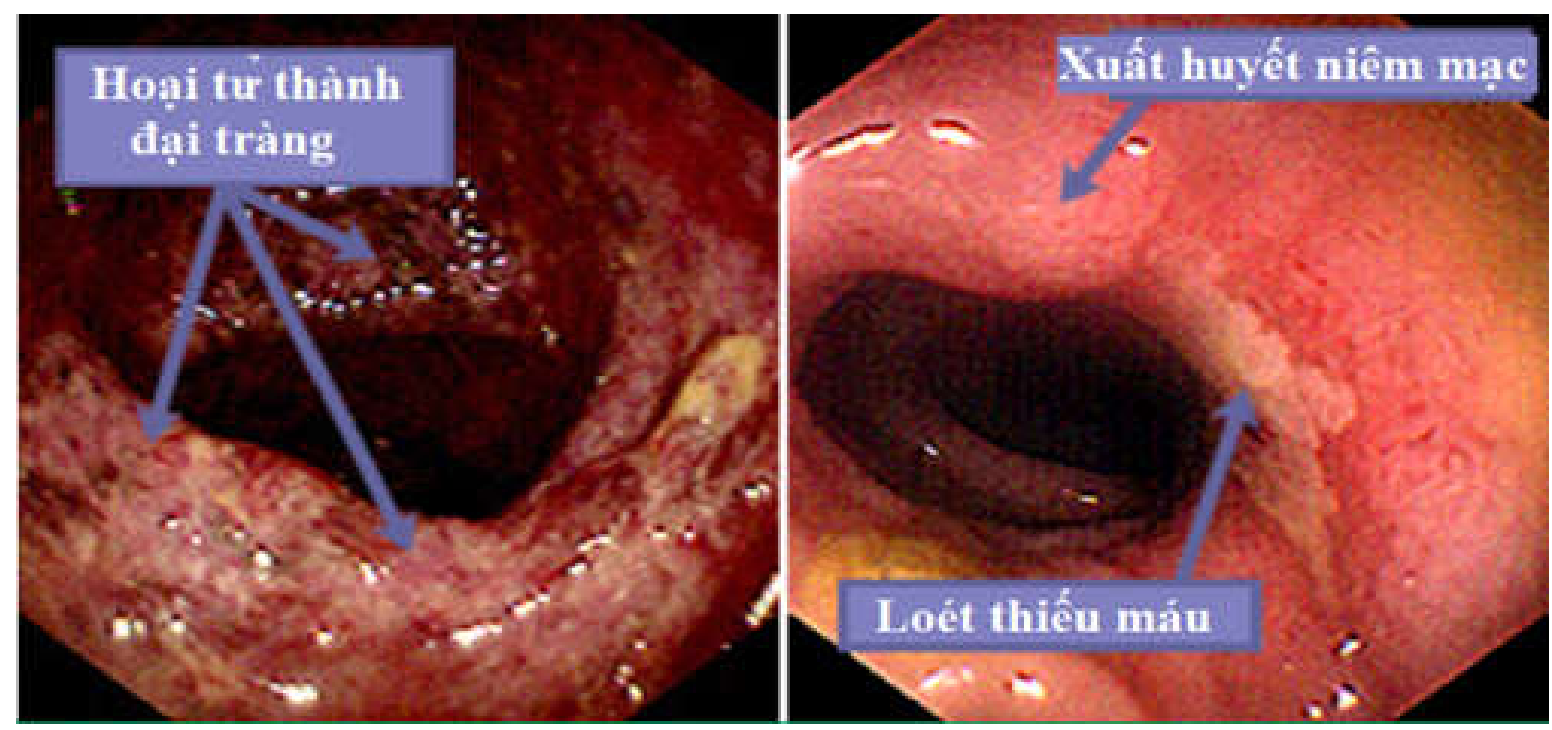

Hình 4. Tổn thương thiếu máu đại tràng phát hiện trên soi đại tràng [15]

Giai đoạn muộn có hoại tử thành đại tràng (trái) và giai đoạn sớm tổn thương khu trú (phải)

Tổn thương thiếu máu đại tràng được chia thành 3 mức độ theo bảng 1 [16]. Ở giai đoạn I và II, khi tổn thương thiếu máu chưa lan rộng, điều trị nội khoa bảo tồn đem lại kết quả tốt. Ở giai đoạn III, chỉ định phẫu thuật đưa ra là cắt đoạn đại tràng hoại tử và làm hậu môn nhân tạo. Đối với những bệnh nhân thuộc nhóm này, tỉ lệ tử vong sau phẫu thuật lên tới trên
$70 \%$. Theo Becquemin, có đến $17 \%$ số bệnh nhân khi được chẩn đoán thiếu máu đại tràng đã biểu hiện tình trạng suy đa tạng và hoại tử đại tràng lan rộng không còn khả năng thực hiện phẫu thuật [3]. Một số nghiên cứu khác đề xuất kỹ thuật can thiệp tái thông ĐMMTTT bằng can thiệp nội mạch đối với những bệnh nhân nghi ngờ nguyên nhân thiếu máu đại tràng do vi tắc mạch, tuy nhiên kết quả vẫn rất hạn chế [17]

Bảng 1. Phân độ tổn thương thiếu máu đại tràng [16]

\begin{tabular}{|l|l|l|}
\hline Phân độ & Tổn thương & Tiên lượng \\
\hline I & Lớp niêm mạc và dưới niêm mạc & $\begin{array}{l}\text { Hồi phục hoàn toàn } \\
\text { Tỉ lệ tử vong thấp }\end{array}$ \\
\hline II & Lớp cơ đại tràng & Có thể hồi phục, số ít tiến triển nặng lên \\
\hline III & Thiếu máu xuyên thành đại tràng & $\begin{array}{l}\text { Rối loạn chuyển hóa } \\
\text { Viêm phúc mạc } \\
\text { Tử vong }>70 \%\end{array}$ \\
\hline
\end{tabular}

Tiên lượng của những bệnh nhân có tổn thương thiếu máu đại tràng sau phẫu thuật thay đoạn ĐMCB còn khá tồi. Nghiên cứu của Klaas chỉ ra rằng tỉ lệ tử vong trong vòng 30 ngày sau phẫu thuật ở nhóm có thiếu máu đại tràng là $21 \%$, trong khi tỉ lệ này ở nhóm không thiếu máu đại tràng chỉ chiếm $1,9 \%(\mathrm{p}<0,001)$. Có đến $90 \%$ số bệnh nhân thuộc nhóm có thiếu máu đại tràng 
phải nằm điều trị tại phòng hồi sức tích cực (ICU) dài hơn 48 tiếng [18]. Mặc dù vậy, các hướng dẫn gần đây nhất cũng chưa đưa ra được các phương pháp cụ thể để làm giảm tỉ lệ biến chứng cũng như tỉ lệ tử vong sau phẫu thuật.

\section{KẾT LUẬN}

Tổn thương thiếu máu đại tràng sau phẫu thuật và can thiệp nội mạch ĐMCB, mặc dù đã được nghiên cứu từ 30 năm nay, nhưng vẫn có tỉ lệ biến chứng và tử vong giảm rất ít qua thời gian. Các hướng dẫn mới nhất cũng không đưa ra được khuyến cáo để làm giảm tỉ lệ biến chứng nặng nề này. Vì vậy, việc phát hiện sớm thương tổn thông qua theo dõi sát các dấu hiệu lâm sàng và thực hiện soi đại tràng hệ thống sau mổ đối với những bệnh nhân có nguy cơ cao có ý nghĩa quyết định trong việc đưa ra chiến lược điều trị tiếp theo. Thêm vào đó, chỉ định can thiệp nội mạch đối với nhóm bệnh nhân nguy cơ cao có thể làm giảm tỉ lệ biến chứng này.

\section{TÀI LIỆU THAM KHẢO}

1. Van DH, Creemers E, Limet R (2000). Ischemic colitis following aortoiliac surgery. Acta Chir Belg, 100,21-27.

2. Bjorck M, Troeng T, Bergqvist D (1997). Risk factors for intestinal ischemia after aortoiliac surgery: a combined cohort and case-control study of 2824 operations. Eur J Vasc Endovasc Surg, 13,531-539.

3. Jean-Pierre Becquemin, Marek Majewski, Nicoletta Fermani et al. (2008). Colon ischemia following abdominal aortic aneurysm repair in the era of endovascular abdominal aortic repair. Journal of vascular surgery, 47(2), 258-263.

4. Christian-Alexander Behrendt, Henrik C.
Rieß, Thea Schwaneberg et al. (2018). Incidence, predictors, and outcomes of colonic ischaemia in abdominal aortic aneurysm repair. Eur J Vasc Endovasc Surg, 56,507-513.

5. Maldonado TS, Rockman CB, Riles E et al. (2004). Ischemic complications after endovascular abdominal aortic aneurysm repair. J Vasc Surg, 40,703-709.

6. Neary P, Hurson C, Briain DO et al. (2007). Abdominal aortic aneurysm repair and colonic infarction: A risk factor appraisal. Colorectal Dis, 9(166-172.

7. Soong CV, Halliday MI, Hood JM et al. (1995). Effect of low-dose dopamine on sigmoid colonic intramucosal $\mathrm{pH}$ in patients undergoing elective abdominal aortic aneurysm repair. $\mathrm{Br} \mathrm{J}$ Surg, 82,912-915.

8. Brewster DC, Franklin DP, Cambria RP et al. (1991). Intestinal ischemia complicating abdominal aortic surgery. Surgery, 109,447-454.

9. Coppi G, Silingardi R, Gennai S et al. (2006). A single-center experience in open and endovascular treatment of hemodynamically unstable and stable patients with ruptured abdominal aortic aneurysms. J Vasc Surg, 44,1140-1147.

10. Pararajasingam R, Weight SC, Bell PR et al. (1999). Endogenous renal nitric oxide metabolism following experimental infrarenal aortic cross-clamp-induced ischaemia-reperfusion injury. Br J Surg, 86,795-799.

11. Khaira HS, Maxwell SR, Thomason H et al. (1996). Antioxidant depletion during aortic aneurysm repair. Br J Surg, 83,401-403.

12. Farooq MM, Freischlag JA, Seabrook 
GR et al. (1996). Effect of the duration of symptoms, transport time, and length of emergency room stay on morbidity and mortality in patients with ruptured abdominal aortic aneurysms. Surgery, 119,9-14.

13. Dadian N, Ohki T, Veith FJ et al. (2001). Overt colon ischemia after endovascular aneurysm repair: the importance of microembolization as an etiology. J Vasc Surg, 34,986-996.

14. Elmarasy NM, Soong CV, Walker SR et al. (2000). Sigmoid ischemia and the inflammatory response following endovascular abdominal aortic aneurysm repair. J Endovasc Ther, 7,21-30.

15. Jonathan A. Levison, Vivienne J. Halpern, Roxana G. Kline et al. (1999). Perioperative predictors of colonic ischemia after ruptured abdominal aortic aneurysm. Journal of vascular surgery, 29(1), 40-47.

16. Tollefson DF, Ernst CB (1991). Colon ischemia following aortic reconstruction. Ann Vasc Surg, 5,485-489.

17. Pol RA, Keus F, Prins TR et al. (2014). Suprarenal fxation resulting in intestinal ischemia after endovascular aortic aneurysm repair. Ann Vasc Surg, 28,5-9.

18. Klaas H.J. Ultee, Sara L. Zettervall, Peter A. Soden et al. (2016). Incidence of and Risk Factors for Bowel Ischemia following Abdominal Aortic Aneurysm Repair. J Vasc Surg, 64(5), 1384-1391. 